\title{
RAZPRAVE
}

\section{GEOMORFOLOŠKE ZNAČILNOSTI IZBRANIH ZATREPNIH DOLIN V SLOVENIJI}

\author{
AVTOR \\ Jure Tičar \\ Znanstvenoraziskovalni center Slovenske akademije znanosti in umetnosti, Geografski inštitut Antona Melika, \\ Gosposka ulica 13, SI - 1000 Ljubljana, Slovenija \\ jure.ticar@zrc-sazu.si
}

DOI: $10.3986 / G V 87102$

UDK: 911.2:551.44(497.4)

COBISS: 1.01

\section{IZVLEČEK}

\section{Geomorfološke značilnosti izbranih zatrepnih dolin $v$ Sloveniji}

Zatrepne doline so značilna površinska reliefna oblika izvirnega kontaktnega krasa. V članku so opisani značilni primeri zatrepnih dolin $v$ Sloveniji. Dosedanje raziskave so se po večini ukvarjale zgolj zopredelitvijo termina, redke pa so bile študije, ki so obravnavale njihove geomorfološke značilnosti. Z obsežnim terenskim delom smo opredelili morfografske in morfometrične značilnosti zatrepnih dolin. Izvedli smo njihovo morfogenetsko interpretacijo, ki se delno opira na obstoječo literaturo, predvsem pa na sintezo geoloških, hidroloških in speleoloških podatkov ter izsledkov s terena. Ugotovili smo, da se zatrepne doline med seboj močno razlikujejo $v$ oblikovanosti. Na njihov razvoj vplivajo kamninska sestava, prelomi, vodoto$k i$, oblikovanost jamskih sistemov $v$ zaledju zatrepnih dolin in raven površinske reliefne oblike, $v$ katero se izteka zatrepna dolina.

\section{KLJUČNE BESEDE}

geomorfologija, krasoslovje, kontaktni kras, zatrepna dolina, morfogeneza, Slovenija

\section{ABSTRACT}

\section{Geomorphological characteristics of selected pocket valleys in Slovenia}

Pocket valleys are typical landforms in the outflow part of contact karst. Examples of pocket valleys were identified and geomorphologicaly examined in detail. Previous studies of pocket valleys have mostly considered the definition of pocket valleys, whereas geomorphological studies have been very rare. The morphographic and morphometric characteristics of pocket valleys were defined through detailed geomorphological examination. Morphogenetic interpretations of pocket valleys were made based in part on existing literature, but mostly based on a synthesis of geological, hydrological, and speleological data with fieldwork results. It was confirmed that the development of pocket valleys is influenced by lithology, geological structure, characteristics of water flow discharge, formation of cave systems in the rim of pocket valley, and the level of regional surface landforms that pocket valleys are located above.

\section{KEY WORDS}

geomorphology, karstology, contact karst, pocket valley, morphogenesis, Slovenia

Uredništvo je prispevek prejelo 27. oktobra 2015. 


\section{Uvod}

Zatrepne doline so značilna površinska reliefna oblika izvirnega kontaktnega krasa. Nastajajo na območju izvirov, kjer vode pritekajo iz kraške kamnine. Izviri se z zadenjsko erozijo zarezujejo v kamnino in sčasoma oblikujejo dolini podobno obliko. V začetku zatrepne doline je nad izvirom strmo pobočje. Dosedanje raziskave zatrepnih dolin so se po večini ukvarjale z opredelitvijo termina, redke pa so bile študije, ki bi obravnavale njihove geomorfološke značilnosti. Takšne raziskave obravnavanih kraških oblik so znane le iz francoske Jure (Frachon 2004) in z območja Planinskega polja (Šušteršič 1977). Tičar (2012) je v svojem diplomskem delu predstavil geomorfološke značilnosti zatrepnih dolin v Sloveniji in Franciji. Značilnosti zatrepnih dolin so v obravnavi razvoja posameznih kraških območij preučevali tudi na območju zatrepne doline Fontaine-de-Vaucluse (Audra s sodelavci 2004; Mocochain, Audra in Bigot 2011) ter Nullarborja v Avstraliji (Lipar in Ferk 2015).

Zatrepne doline je pri nas prvi omenil Melik (1928), ki opisuje primere »zagatnih dolin«, ki se zgoraj zaključujejo s strmim in zelo visokim dolinskim sklepom, pod katerim izvira kraška voda. V tuji literaturi jih prvi omenja v Fourne leta 1852 (Frachon 2004, 109), ki pojasnjuje razvoj udornih dolin (francosko vallée d'effondrement).

V slovenski literaturi je za omenjene površinske reliefne oblike izvirnega kontaktnega krasa najpogosteje uporabljena oznaka zatrepna dolina (Gams 1973; 2004; Šušteršič 1977; Kranjc 2001; Kladnik, Lovrenčak in Orožen Adamič 2005; Tičar 2012). Izraz se pogosto napačno zamenjuje z izrazom zatrep, ki označuje zgolj začetek zatrepne doline oziroma samostojno površinsko obliko. Ker je v primeru Planinskega zatrepa že prišlo do širše uporabe izraza zatrep v literaturi, smo izraz v članku ohranili.

$\mathrm{V}$ angleški literaturi je najpogosteje uporabljen izraz za zatrepno dolino pocket valley, v ameriški pa je pogostejša uporaba izraza steephead oziroma steephead valley (Ford in Williams 2007), redkeje

Slika 1: Planinski zatrep uvrščamo med značilne zatrepne doline.

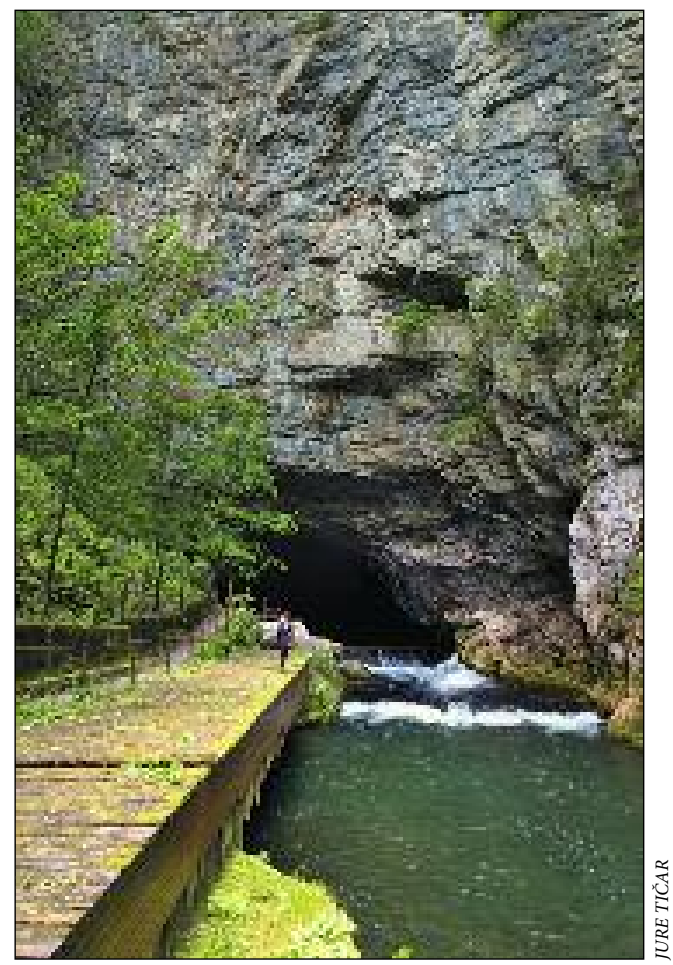


spring allove (Gams 1973). V francoski literaturi je splošno uveljavljen izraz za zatrepno dolino reculée, pojavljajo pa se še različice, kot so cul-de-sac, bout de monde, fin du monde, couronnes, corniches (Salomon 2006), vallée en cul-de-sac in cirque (Frachon 2004). V Slovenski kraški terminologiji (Gams 1973) so omenjeni še izrazi, ki se uporabljajo v nemški literaturi, in sicer Karstsacktall in Sacktall.

Izraz zatrep, uporabljen $\mathrm{v}$ članku, se navezuje na strm, pogosto stenast začetek zatrepne nad sedanjim ali nekdanjim izvirom $\mathrm{v}$ zatrepni dolini, lahko pa označuje tudi samostojno površinsko obliko, na primer zatrep Hublja. Podobno uporabo izraza lahko zasledimo tudi v sorodni geomorfološki literaturi (Mihevc 1991), in sicer "ponorni zatrep«, vendar se ta navezuje na strme stene ob sedanjih ali nekdanjih ponorih vodotokov v slepih dolinah.

Slovenska kraška terminologija podaja le skromno definicijo o zatrepnih dolinah, in sicer, da je »...dolina na krasu, ki se na zgornjem koncu, često ob izviru potoka, slepo konča s strmim zaključkom." (Gams 1973, 27). Podobno skromno definicijo podajata tudi Geografski terminološki slovar (Kladnik, Lovrenčak in Orožen Adamič 2005) in Geološki terminološki slovar (Pavšič 2006). Slednji zatrep povezuje zgolj s slepo dolino.

Pri pregledu literature smo poseben poudarek namenili predvsem procesom, $s$ katerimi naj bi zatrepne doline nastale. Njihov nastanek smo tako glede na preučeno literaturo razdelili na strukturni, korozijski, erozijski in udorni.

Pomen strukturnega nastanka ob prelomnih strukturah omenjajo le redki avtorji, ki navajajo definicije zatrepnih dolin. Gams (2004) navaja, da na dolžino zatrepne doline vplivajo tudi starost, lastnosti kamnine, prevotljenost in to, ali na koncu doline voda priteka navpično navzgor ali vodoravno iz jame. Avtorji, ki so se podrobneje ukvarjali z razvojem zatrepnih dolin, omenjajo prelome kot ključne za nastanek zatrepnih dolin, saj so se le-te razvile vzdolž prelomnih struktur (Šušteršič 1977; Frachon 2004; Lipar in Ferk 2015). Frachon (2004) v študiji zatrepnih dolin v Juri ugotavlja, da so se spremembe v izoblikovanosti pobočij pojavljale predvsem zaradi sprememb kamnine, saj so apnenci odloženi nad plastmi laporjev. Tako so pobočja $\mathrm{v}$ apnencih po večini stenasta oziroma zelo strma, v laporjih pa položnejša.

Korozija ima pri nastanku zatrepnih dolin le posredni pomen, saj po mnenju Šušteršiča (1977), Kranjca (2001) in Gamsa (2004) vpliva le na raztapljanje okruškov in gradiva, ki ga pobočni procesi prenesejo $\mathrm{v}$ strugo vodotoka.

Erozija naj bi bila po mnenju številnih avtorjev ključna za nastanek zatrepnih dolin. Avtorji omenjajo, da zatrepne doline nastajajo ob izvirih potokov z zadenjsko erozijo, ki spodkopava kamnino (Šušteršič 1977; Kranjc 2001; Frachon 2004; Goudie 2004; Gunn 2004; Ford in Williams 2007; Hugget 2007; Lipar in Ferk 2015). Hugget (2007) dopušča tudi možnost, da nekatere zatrepne doline niso hidrološko aktivne. Po Šušteršiču (1977) naj bi zatrepi nastali kot delovanje dveh dejavnikov, in sicer erozijskih ter transportnih zmožnosti vodotoka in zasipanja dna korita iz izvira s sedimenti. Kranjc (2001) pa pri njihovem nastajanju izpostavlja razmerje med erozijskimi in pobočnimi procesi.

Šušteršič (1977) v daje velik poudarek geološki sestavi, saj naj bi zatrepi nastajali povsod, kjer je umikanje pobočij nad kraškim izvirom hitrejše od umikanja pobočij v okolici. Zatrepi naj bi bili po njegovem mnenju podorne tvorbe. Kot možnost nastanka zatrepnih dolin Goudie (2004) in Hugget (2007) omenjata tudi porušitev jamskega stropa. Kranjc (2001) navaja tudi povezanost z udornicami, saj naj bi bile na mestih, kjer je podzemeljski vodni rov plitvo pod površjem; poleg tega so v zaledju zatrepne doline pogoste udornice. Salomon (2006) navaja, da je razvoj zatrepnih dolin močno odvisen od značilnosti geološke sestave. Zatrepne doline so po njegovem mnenju povezane $\mathrm{z}$ večjimi izviri, poleg tega naj bi se nad takimi dolinami večkrat nadaljevale suhe doline oziroma linije vrtač. V tem primeru naj bi bilo očitno, da se podzemni jamski sistemi preslikujejo na površje in pozneje z udori tvorijo zatrepno dolino.

Med značilne zatrepne doline, ki jih postavlja v ospredje tuja literatura (Frachon 2004; Gunn 2004; Salomon 2006; Ford in Williams 2007; Hugget 2007), se uvrščajo doline Malham Cove, Punch Bowl in Marble Arch v Angliji; Fontaine-de-Vaucluse, Baume-les-Messieurs, Lison, Sorpt, Saint-Guilhem-le-Désert, Autoire, Amancey, Cuisance, Glantine, Seille in Vallière v Franciji ter Honau in Urach v Nemčiji. 
V Sloveniji med značilne zatrepne doline uvrščajo (Šušteršič 1977; Kranjc 2001; Gams 2004): Močilnik in Retovje na izviru Ljubljanice, Planinski zatrep in zatrepno dolino Malni na Planinskem polju, zatrepno dolino Luknja na izviru Prečne, zatrepno dolino na izviru Krke, Krupe, zatrepno dolino Kroparice, zatrepno dolino Divje jezero pri Idriji in zatrepno dolino Hubelj.

\section{Opisi zatrepov}

V Sloveniji smo preučili tri različna kraška območja, na katerih so se razvile zatrepne doline. V začetku je bilo preučeno območje izvirov Ljubljanice, kjer sta se izoblikovali zatrepni dolini Retovje in Močilnik. Sledile so raziskave obrobja Planinskega polja, na katerem sta zatrepni dolini Malni in Planinski zatrep. Raziskave pa smo sklenili v porečju reke Krke, kjer so bile preučene zatrepne doline Globočec, Luknja in Studena. Skupaj je bilo preučenih sedem zatrepnih dolin, ki smo jih izbrali na podlagi izpostavljenosti v literaturi ter morfološke razvitosti.

\subsection{Območje izvirov Ljubljanice}

\subsubsection{Zatrepna dolina Retovje}

Zatrepna dolina Retovje (slika 2) leži na skrajnem severnem robu Menišije v zgornjejurskem drobnooolitnem apnencu in dolomitu. Na območju zatrepne doline prevladujejo prelomi v smeri severozahod-jugovzhod (Buser, Grad in Pleničar 1967). V zatrepni dolini Retovje so štirje izviri, ki se združujejo v Veliko Ljubljanico. V glavnem zatrepu je izvir Veliko Okence, v stranskem zatrepu pa izvir Malo Okence, ki ob nizkem vodostaju povsem presahneta. Povprečni pretok Velike Ljubljanice je $16,45 \mathrm{~m}^{3} / \mathrm{s}$, pretok v času obilnih padavin narase do $73,3 \mathrm{~m}^{3} / \mathrm{s}$, v času nizkih vodostajev pa upade do $0,22 \mathrm{~m}^{3} / \mathrm{s}$ (Arhiv ... 2015b). Na območju zatrepne doline so raziskane štiri izvirne freatične jame. Najdaljša jama je Malo Okence, raziskana v dolžini 360 m, v zatrepu Veliko Okence pa se odpira 267 m dolga istoimenska jama (Kataster jam 2015).

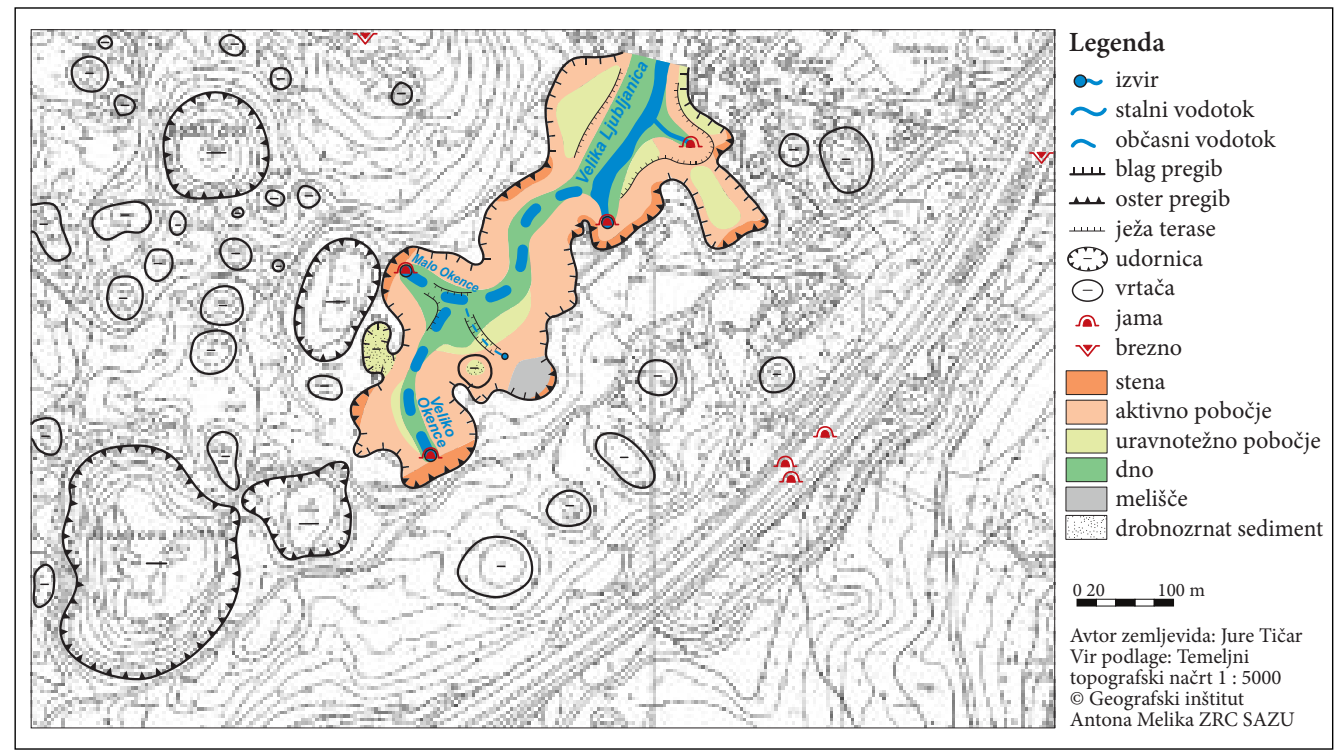

Slika 2: Geomorfološki zemljevid zatrepne doline Retovje. 


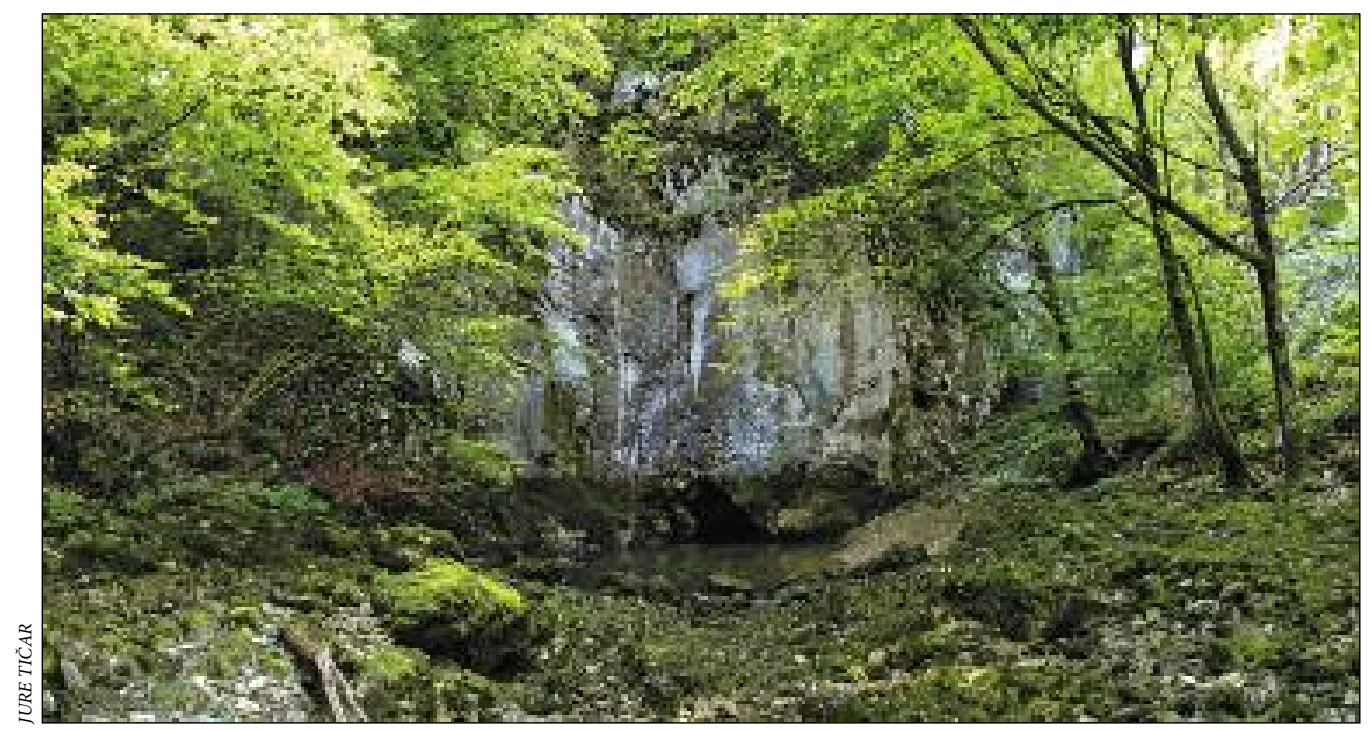

Slika 3: Zatrep Veliko Okence ob suši povsem presuši, ob obilici deževja pa je glavni izvir Ljubljanice.

Dolžina zatrepne doline med vrhom glavnega zatrepa in iztekom je $490 \mathrm{~m}$, skupaj s tremi stranskimi zatrepi pa $770 \mathrm{~m}$. Širina zatrepne doline je med $60 \mathrm{~m}$ pri mostu zahodno od zatrepa Pod skalo in $200 \mathrm{~m}$ ob izteku zatrepne doline. Dno zatrepne doline je z 90 m najširše ob zatrepu Malo Okence, z 20 m pa najožje za zatrepom Veliko Okence; prekriva ga grušč. Izvir Velike Ljubljanice v Velikem Okencu (slika 3) se pojavlja v nadmorski višini $298 \mathrm{~m}$, nad njim pa je $15 \mathrm{~m}$ visoka stena. V vršnih delih pobočij zatrepne doline Retovje so ostenja, ki so strmejša v hidrološko aktivnejših zatrepih. Manjši zatrep je tudi nasproti Malega Okenca, v njegovem jugozahodnem delu pa je manjša vrtača, odprta proti zatrepni dolini in zapolnjena $\mathrm{z}$ ilovico. Ta ilovica je odložena v podobni nadmorski višini $(296 \mathrm{~m})$, kot je izoblikovana terasa v južnem delu Malega Okenca. Iztek zatrepne doline je v nadmorski višini $289 \mathrm{~m}$. Povprečni naklon dna med izvirom Veliko Okence in iztekom zatrepne doline je $1,05^{\circ}$, naklon površja v obodu zatrepne doline pa $1,17^{\circ}$.

\subsubsection{Zatrepna dolina Močilnik}

Zatrepna dolina Močilnik (slika 4) je nastala v podobnih geoloških razmerah kot zatrepna dolina Močilnik (Buser, Grad in Pleničar 1967). V dolini so štirje izviri med katerimi je največji Veliki Močilnik, ki se skupaj z Malim Močilnikom združi v Malo Ljubljanico. Povprečni pretok Male Ljubljanice je $7,62 \mathrm{~m}^{3} / \mathrm{s}$, pretok v času obilnih padavin narase do $27,3 \mathrm{~m}^{3} / \mathrm{s}$, v času nizkih vodostajev pa pretok upade do $0,19 \mathrm{~m}^{3} / \mathrm{s}$ (Arhiv ... 2015a). V zatrepni dolini Močilnik je registrirana jama Mali Močilnik (Kataster jam 2015).

Dolžina zatrepne doline med vrhom zatrepa in iztekom je $540 \mathrm{~m}$, njena širina pa med $70 \mathrm{~m} \mathrm{v}$ zatrepu in $450 \mathrm{~m}$ v izteku. Izvir Velikega Močilnika je na nadmorski višini $295 \mathrm{~m}$, nad njim pa je $40 \mathrm{~m}$ visok stenast zatrep. Dno zatrepne doline je s 390 m najširše ob izteku, s 30 m pa najožje v zatrepu. Dno je prekrito z gruščem in naplavinami, vanj pa so vrezane vode Male Ljubljanice in njenih pritokov. Vzhodno od mostu je na nadmorski višini okrog $295 \mathrm{~m} 120 \mathrm{~m}$ dolga in $30 \mathrm{~m}$ široka terasa. Na zahodni strani zatrepne doline je obsežna naplavna ravnica, ki je dolga približno $250 \mathrm{~m}$ in široka $180 \mathrm{~m}$ ter sega do pritoka Malega Močilnika. Iztek zatrepne doline je v nadmorski višini 290 m. Povprečni naklon med izvirom Velikega Močilnika in iztekom zatrepne doline je $0,53^{\circ}$, naklon površja v obodu zatrepne doline pa $3,72^{\circ}$. 


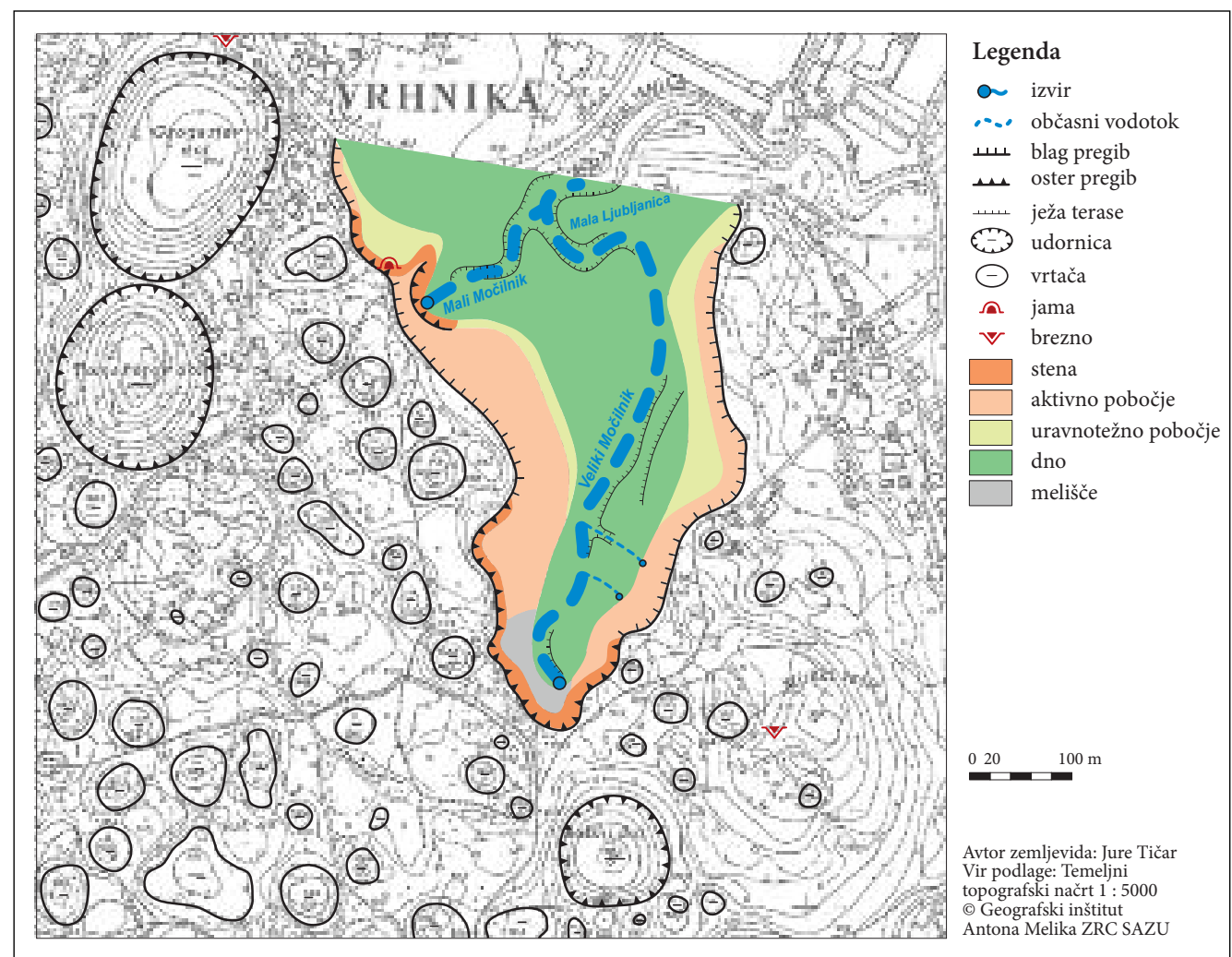

Slika 4: Geomorfološki zemljevid zatrepne doline Močilnik.

\subsection{Območje Planinskega polja}

\subsubsection{Planinski zatrep in zatrepna dolina Malni}

Zatrepni dolini Planinski zatrep in Malni sta na skrajnem jugozahodnem robu Planinskega polja v spodnjekrednih ploščatih apnencih z vložki dolomita (Buser, Grad in Pleničar 1967). Območje Planinskega zatrepa in njenega zaledja sekajo številni prelomi v dinarski smeri severozahod-jugovzhod, ponekod pa so tudi prelomi v smeri sever-jug. Osrednji del zatrepne doline Malni prečka antiklinala, medtem ko je zatrep v sinklinali (Čar in Gospodarič 1983). V Planinskem zatrepu (slika 5) izvira reka Unica, katere pretoki močno nihajo, saj ima reka v času obilnih padavin pretok več kot $100 \mathrm{~m}^{3} / \mathrm{s}$, medtem ko je ob nizkih vodostajih njen pretok le $1,1 \mathrm{~m}^{3} / \mathrm{s}$. Povprečen pretok Unice je $21 \mathrm{~m}^{3} / \mathrm{s}$ (Frantar 2008). Približno $300 \mathrm{~m}$ severno od Planinskega zatrepa se v reko Unico stekajo vode izvira Cvinger, ki pa ima zelo malo vode.

V zatrepni dolini Malni (slika 6) so štirje izviri, med katerimi je najpomembnejši izvir Malenščice v osrednjem delu doline. Njen povprečen pretok je $6,7 \mathrm{~m}^{3} / \mathrm{s}$, pretok $\mathrm{v}$ času obilnih padavin narase na nekaj več kot $10 \mathrm{~m}^{3} / \mathrm{s}$, ob nizkih vodostajih pa je pretok približno $1,1 \mathrm{~m}^{3} / \mathrm{s}$. Srednji izvir ob nizkih vodostajih povsem presahne, $\mathrm{v}$ času obilnih padavin pa prispeva do $4 \mathrm{~m}^{3} / \mathrm{s}$. Zgornji izvir in izvir v Laškarjevem kotu sta aktivna zgolj ob najvišjih vodostajih, ko skupaj prispevata do $1 \mathrm{~m}^{3} / \mathrm{s}$. Ob nizkih vodostajih so izviri Malenščice glavni vodni vir na Planinskem polju, v času obilnih padavin pa prispevajo zgolj okrog desetine vode (Kovačič 2011). 


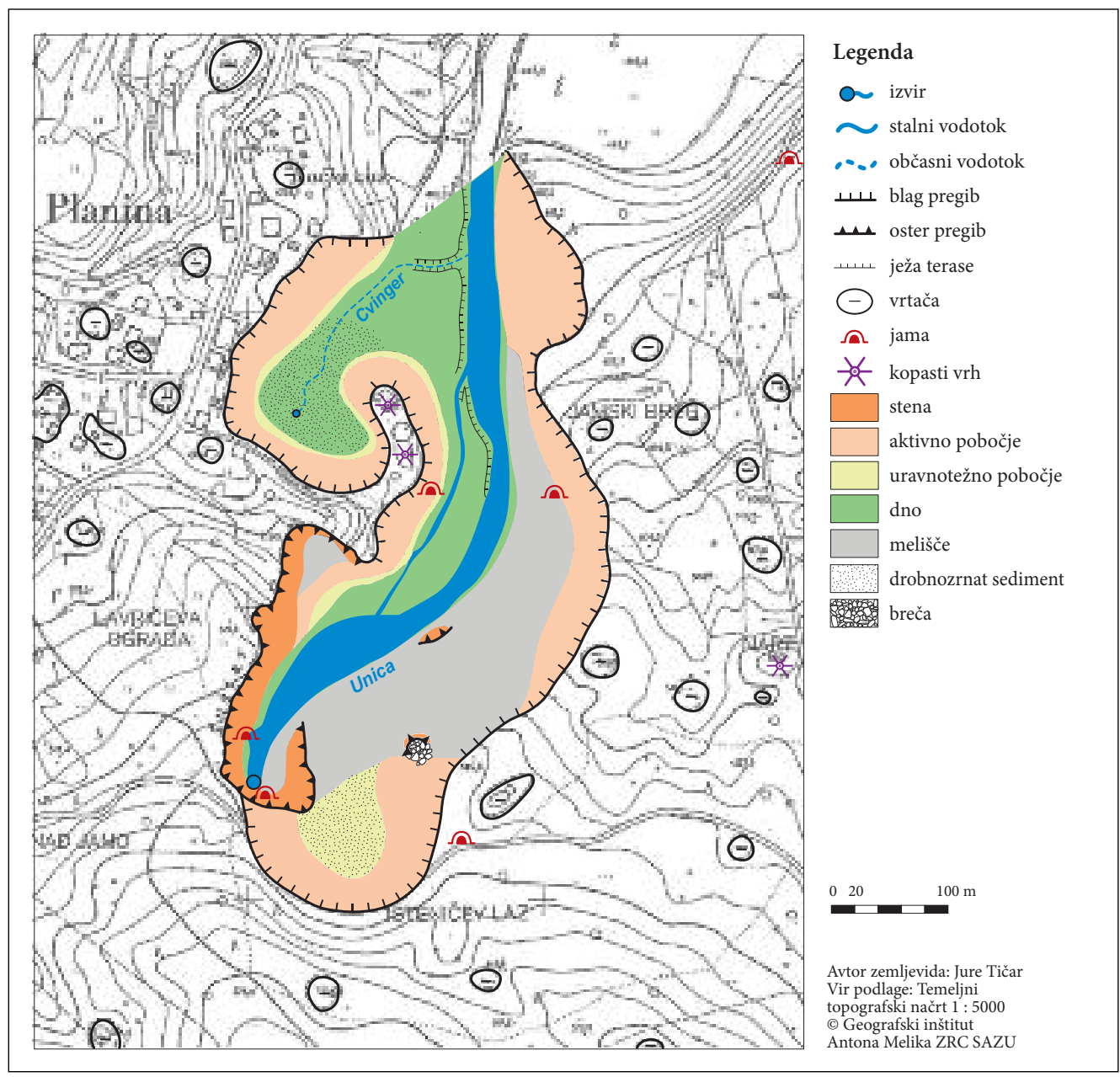

Slika 5: Geomorfološki zemljevid zatrepne doline Planinski zatrep.

Na območju Planinskega zatrepa je pet jam, v zatrepni dolini Malni pa štiri. Največja jama na tem območju je $6656 \mathrm{~m}$ dolga paragenetsko preoblikovana Planinska jama (Kataster jam 2015).

Dolžina zatrepne doline Planinski zatrep med vrhom zatrepa in iztekom je $660 \mathrm{~m}$, skupaj z zatrepom Cvinger pa $920 \mathrm{~m}$. Širina zatrepne doline variira med $170 \mathrm{~m}$ v glavnem zatrepu in $270 \mathrm{~m}$ za zatrepom Cvinger. Reka Unica izvira na nadmorski višini $453 \mathrm{~m}$, nad izvirom pa se dviga glavni zatrep. Sestavlja ga $85 \mathrm{~m}$ visoko ostenje, ki se na desnem bregu nadaljuje okrog $200 \mathrm{~m}$ v smeri zatrepa Cvinger, na levem bregu pa v daljše sklenjeno melišče. Nad glavnim zatrepom je udornica, ki zapolnjuje večji vzhodni rov v vhodnem delu Planinske jame. Dno zatrepne doline je s $130 \mathrm{~m}$ najširše za Cvingerjem, najožje pa s $25 \mathrm{~m}$ v rečni strugi za izvirom. Dno v začetku popolnoma zapolnjuje struga reke Unice, ki teče po matični podlagi in podornem gradivu ter se ob izteku vrezuje v lastne naplavine. Iztek zatrepne doline je na nadmorski višini $448 \mathrm{~m}$. Povprečni naklon med izvirom Unice in iztekom zatrepne doline je $0,43^{\circ}$, naklon površja v obodu zatrepne doline pa $6,09^{\circ}$.

Dolžina zatrepne doline Malni med vrhom zatrepa in iztekom je $1200 \mathrm{~m}$. Širina zatrepne doline je približno $350 \mathrm{~m}$. Dno zatrepne doline je s $180 \mathrm{~m}$ najširše ob izteku, v osrednjem delu pa je široko med 


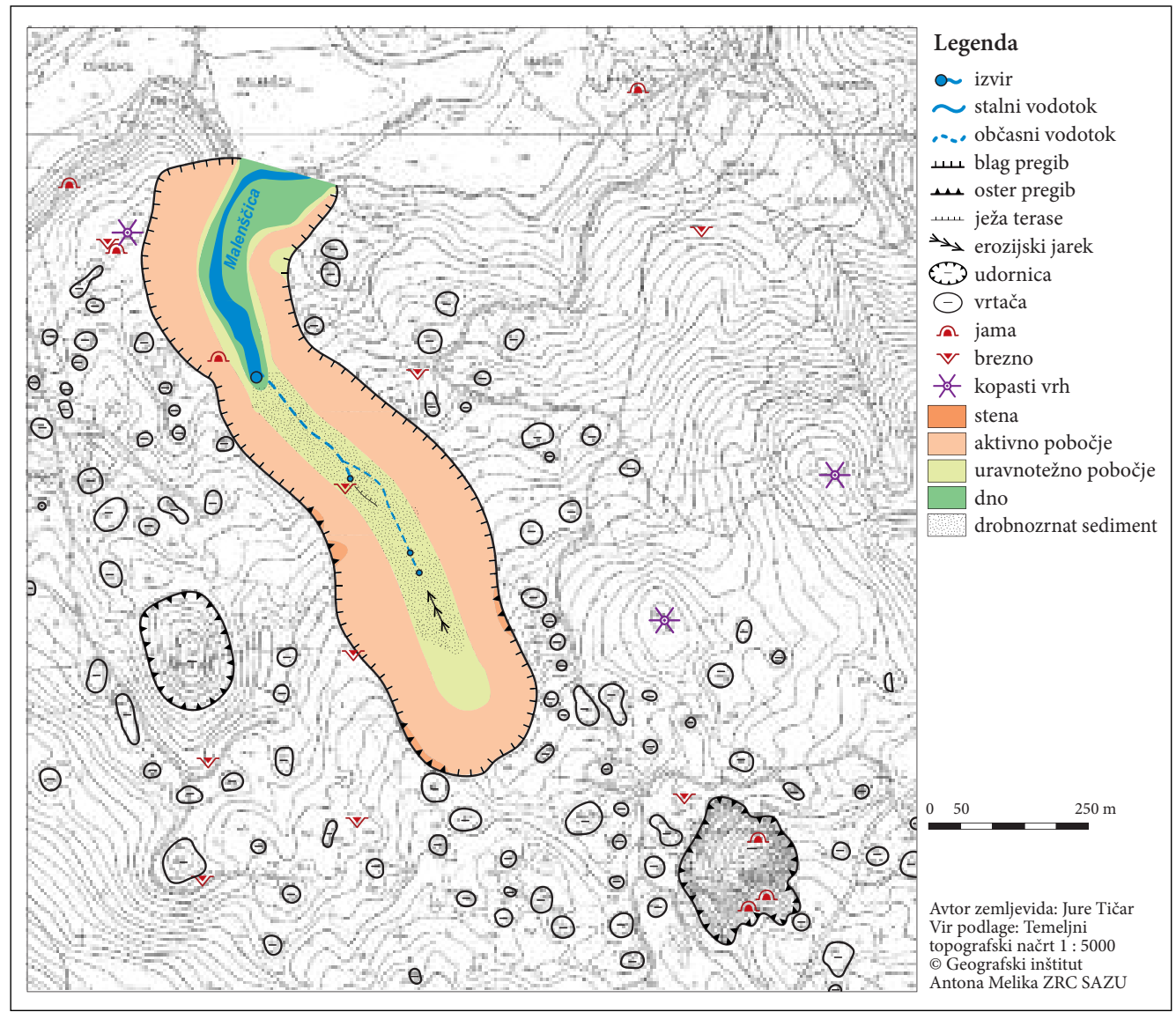

Slika 6: Geomorfološki zemljevid zatrepne doline Malni.

$40 \mathrm{~m}$ in $50 \mathrm{~m}$. Malenščica izvira približno $370 \mathrm{~m}$ pred iztekom zatrepne doline v nadmorski višini $448 \mathrm{~m}$, zatrepna dolina pa nima stenastega zatrepa, temveč aktivna pobočja $\mathrm{v}$ katerih potekajo pobočni procesi. Dno zatrepne doline je pod zatrepom v višini $510 \mathrm{~m}$, nato pa se do glavnega izvira znižuje do nadmorske višine okrog $448 \mathrm{~m}$. Do nadmorske višine okrog $495 \mathrm{~m}$ dno zatrepa zapolnjuje naplavna ilovica, ki ji je ob stiku z aktivnimi pobočji primešan pobočni grušč (Stepišnik s sodelavci 2012). Nad srednjim izvirom je v zahodnem pobočju $2 \mathrm{~m}$ visoka terasa, ki jo sestavlja ilovnat sediment. Iztek zatrepne doline je v nadmorski višini $446 \mathrm{~m}$. Povprečni naklon med dnom v zatrepu in izvirom Malenščice je $4,28^{\circ}$ med izvirom in iztekom zatrepne doline $0,31^{\circ}$, naklon površja v obodu zatrepne doline pa $2,87^{\circ}$.

\subsection{Porečje Krke}

\subsubsection{Zatrepna dolina Globočec}

Zatrepna dolina Globočec (slika 7) leži na desnem bregu Krke jugozahodno od naselja Zagradec. Nastala je v spodnjejurskih apnencih, ki se menjavajo s pasovitim dolomitom. Približno $200 \mathrm{~m}$ jugovzhodno od zatrepne doline območje prečka močen prelom v smeri severovzhod-jugozahod (Buser 1968). V glavnem zatrepu zatrepne doline Globočec so trije izviri. Povprečni pretoki v glavnem izviru so med 


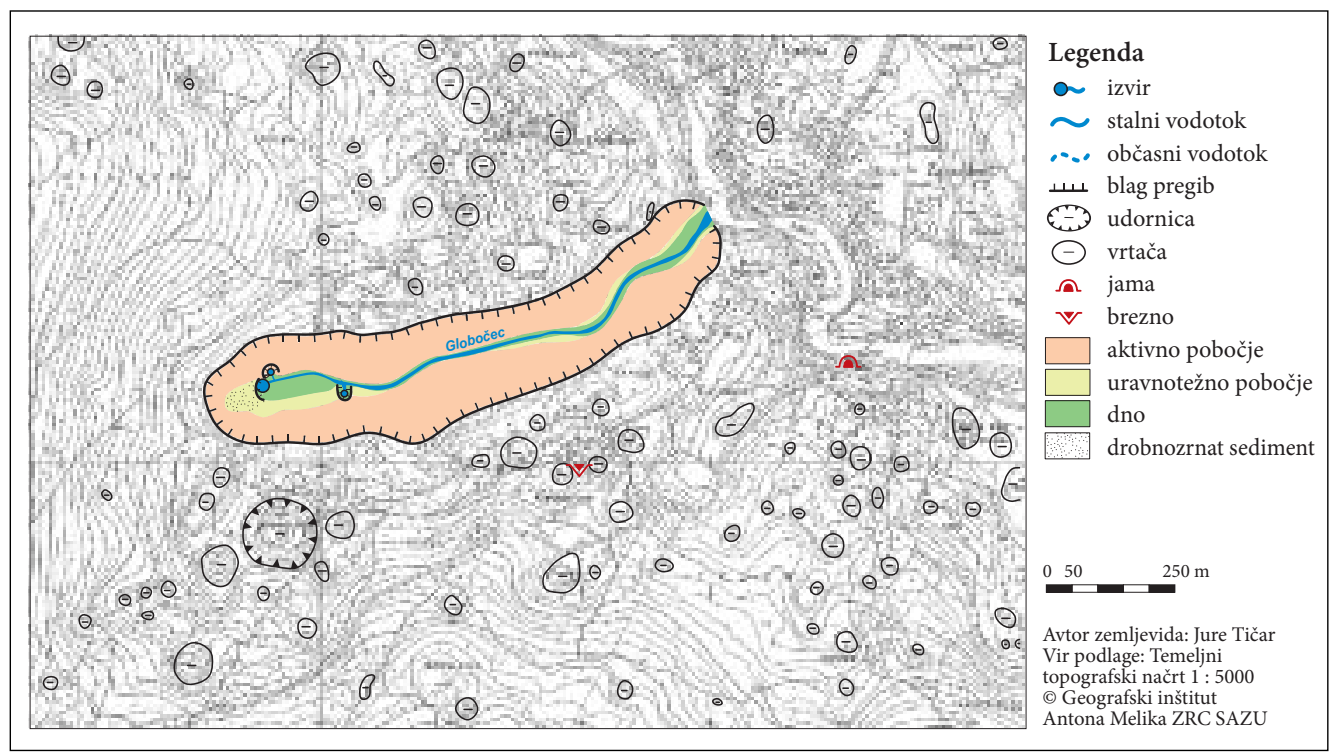

Slika 7: Geomorfološki zemljevid zatrepne doline Globočec.

1 in $1,5 \mathrm{~m}^{3} / \mathrm{s}$, medtem ko so bili najnižji izmerjeni pretoki $0,093 \mathrm{~m}^{3} / \mathrm{s}$. Proti izviru se stekajo vode z južnega dela dobrepoljske kotline, Struge in padavinskega zaledja Tržiščice (Novak 1985), novejše raziskave pa so dokazale dotok vode ob obilnih padavinah tudi iz smeri Male gore (Kogovšek in Petrič 2006).

Dolžina zatrepne doline med vrhom zatrepa in iztekom je $1130 \mathrm{~m}$. Širina zatrepne doline je v začetnem in osrednjem delu približno $250 \mathrm{~m}$ in je precej homogena, pri izteku pa se zoži na približno $100 \mathrm{~m}$. Izvir Globočca je v nadmorski višini 248 m, nad njim pa je zatrep z aktivnimi pobočji, kjer prevladujejo pobočni procesi. Dno zatrepne doline je s $60 \mathrm{~m}$ najširše v območju zatrepa, v preostalem delu zatrepne doline pa je široko 10-20 m. Iztek zatrepne doline je v nadmorski višini $240 \mathrm{~m}$. Povprečni naklon med izvirom Globočca in iztekom zatrepne doline je $0,41^{\circ}$, naklon površja v obodu zatrepne doline pa $1,27^{\circ}$.

\subsubsection{Zatrepna dolina Luknja}

Zatrepna dolina Luknja (slika 8) leži na zahodnem robu Krško-Brežiške kotline, v zgornjejurskih skladovitih in oolitnih apnencih, ki ponekod prehajajo v plasti dolomita ali dolomitnega apnenca (Pleničar, Premru in Herak 1975). Izvir Prečna je eden izmed večjih kraških izvirov v porečju Krke. Tu izvirajo vode iz obširnega zaledja vzhodne Suhe krajine (Habič s sodelavci 1976). V zatrepni dolini so trije izviri, in sicer stalni izvir pod gradom Luknja, občasni izvir v manjšem severnem zatrepu in izvir pri Lukenjski jami. Povprečni pretok Prečne je $4,6 \mathrm{~m}^{3} / \mathrm{s}$, pretok v času obilnih padavin narase do $21,8 \mathrm{~m}^{3} / \mathrm{s}, \mathrm{v}$ času nizkih vodostajev pa upade do $0,56 \mathrm{~m}^{3} / \mathrm{s}$ (Kogovšek in Petrič 1998). Na območju zatrepne doline je osem jam. Največja je $307 \mathrm{~m}$ dolga Lukenjska jama, ki je razvita v epifreatični coni, njen vhod pa se odpira na nadmorski višini $167 \mathrm{~m}$. V glavnem zatrepu se nad izvirom odpirajo vhodi v pet jam v nadmorskih višinah med $188 \mathrm{~m}$ in $193 \mathrm{~m}$ (Kataster jam 2015).

Dolžina zatrepne doline med vrhom glavnega zatrepa in iztekom je $870 \mathrm{~m}$, skupaj s stranskim zatrepom pa $1140 \mathrm{~m}$. Širina zatrepne doline je med $500 \mathrm{~m}$ v zatrepu in $400 \mathrm{~m}$ v izteku. Izvir Prečne je na nadmorski višini 173 m, v njegovem zaledju pa je v nadmorski višini 190-195 m nekdanji zatrep, nad katerim je $60 \mathrm{~m}$ visoko ostenje. Severno nad glavnim zatrepom je v nadmorski višini približno $240 \mathrm{~m}$ najstarejši zatrep. V njegovem dnu so večje količine ilovnatega sedimenta, pobočja v njem pa so uravnotežena. 
V severozahodnem delu oboda zatrepne doline je manjši erozijski jarek. Dno zatrepne doline je s $160 \mathrm{~m}$ najširše med obema zatrepoma, z 20 m pa najožje v osrednjem delu zatrepne doline. V osrednjem delu se dno močno zoži, Prečna pa je približno $1 \mathrm{~m}$ globoko vrezana v lastne ilovnate naplavine. Iztek zatrepne doline je v nadmorski višini $168 \mathrm{~m}$. Povprečni naklon med izvirom Prečne in iztekom zatrepne doline je $0,33^{\circ}$, naklon površja v obodu zatrepne doline pa $3,95^{\circ}$.

\subsubsection{Zatrepna dolina Studena}

Zatrepna dolina Studena (slika 9) je v osrednjem delu vznožja Gorjancev v spodnjekrednih apnencih z vložki dolomitiziranega apnenca in dolomita, ki sestavljajo južni in jugovzhodni del zatrepne doline, njen vzhodni in severni del pa je v zgornjekredni apnenčevi breči (Pleničar, Premru in Herak 1975). V zatrepni dolini so štirje izviri. Največji med njimi je stalni izvir Studêne iz Kostanjeviške jame, močni pa so tudi pritoki iz severnega dela, iz Bizjakove jame, kjer izvir presahne le ob nižjih vodostajih. Povprečni pretok Studene je $0,6 \mathrm{~m}^{3} / \mathrm{s}$, pretok v času obilnih padavin narase do $18,5 \mathrm{~m}^{3} / \mathrm{s}, \mathrm{v}$ času nizkih vodostajev pa pretok upade do $0,09 \mathrm{~m}^{3} / \mathrm{s}$ (Novak 2001). Na območju zatrepne doline je pet jam. S 1871 m je največja Kostanjeviška jama (slika 12), ki je nastala v epifreatičnih razmerah, njeni rovi pa se končajo približno $100 \mathrm{~m}$ pred udornico Banova jama. Druga večja jama na območju zatrepne doline je Bizjakova jama, ki je dolga $558 \mathrm{~m}$ in jo sestavlja splet vodnih rovov, ki potekajo proti vzhodu v smeri Globočic (Kataster jam 2015).

Zatrepna dolina je dolga $750 \mathrm{~m}$, skupaj s stranskim zatrepom pa $870 \mathrm{~m}$. Širina zatrepne doline je med $230 \mathrm{~m}$ v zatrepu in $330 \mathrm{~m}$ v izteku. Studena izvira v nadmorski višini $158 \mathrm{~m}$, nad njo pa se dvigajo aktivna pobočja. Pobočja na desnem bregu so po večini aktivna, pobočja na levem bregu uravnotežena. Večja ostenja se pojavljajo zgolj v zatrepih. Dno zatrepne doline je z $210 \mathrm{~m}$ najširše v izteku, s $50 \mathrm{~m}$ pa

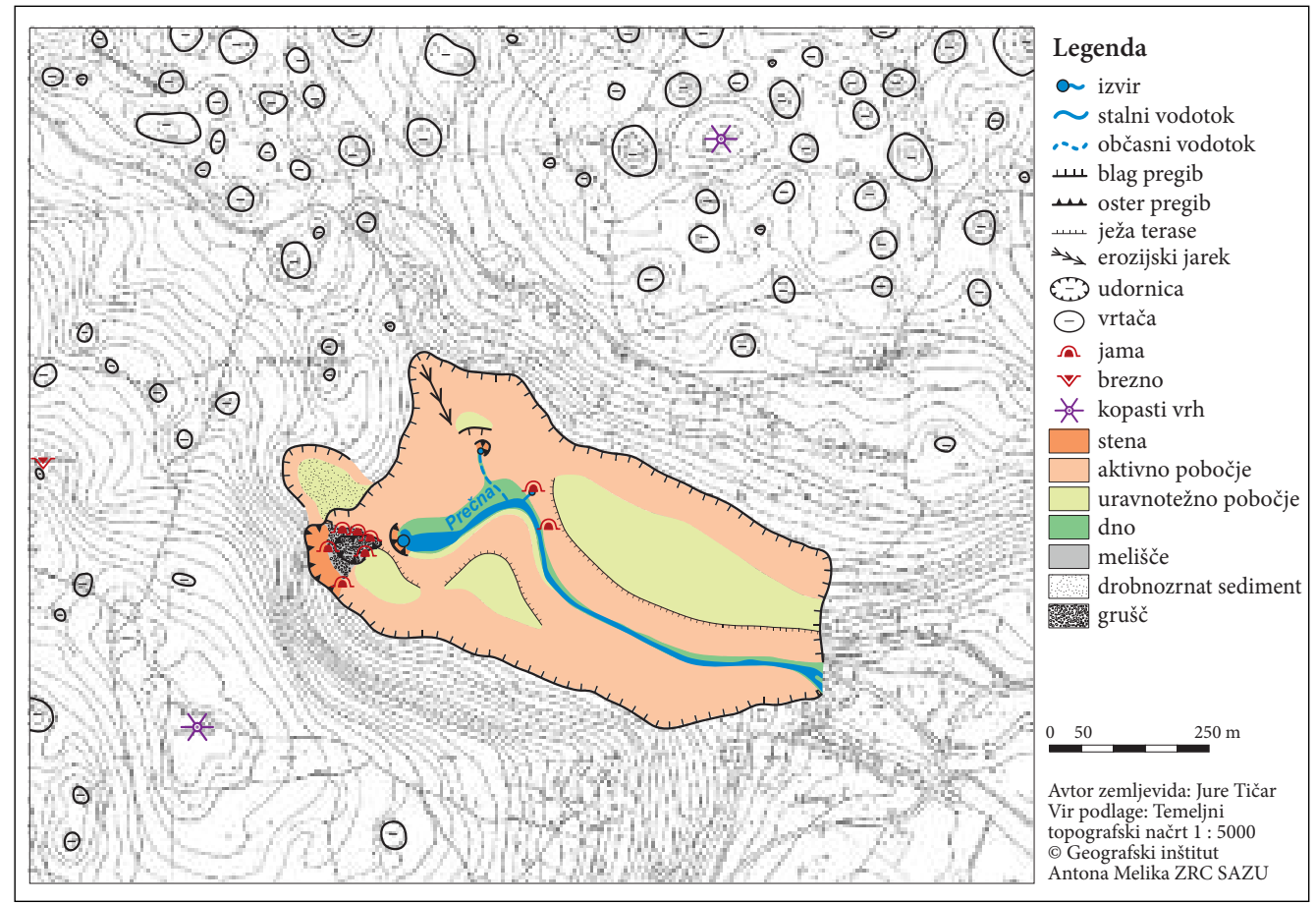

Slika 8: Geomorfološki zemljevid zatrepne doline Luknja. 
najožje v osrednjem delu zatrepne doline. Dno je v celoti prekrito z gruščem (slika 10), Studena pa je zarezana 1-2 m globoko v naplavine. Iztek zatrepne doline je v nadmorski višini $153 \mathrm{~m}$. Povprečni naklon med izvirom Studene in iztekom zatrepne doline je $0,38^{\circ}$, naklon površja v obodu zatrepne doline pa $1,91^{\circ}$.

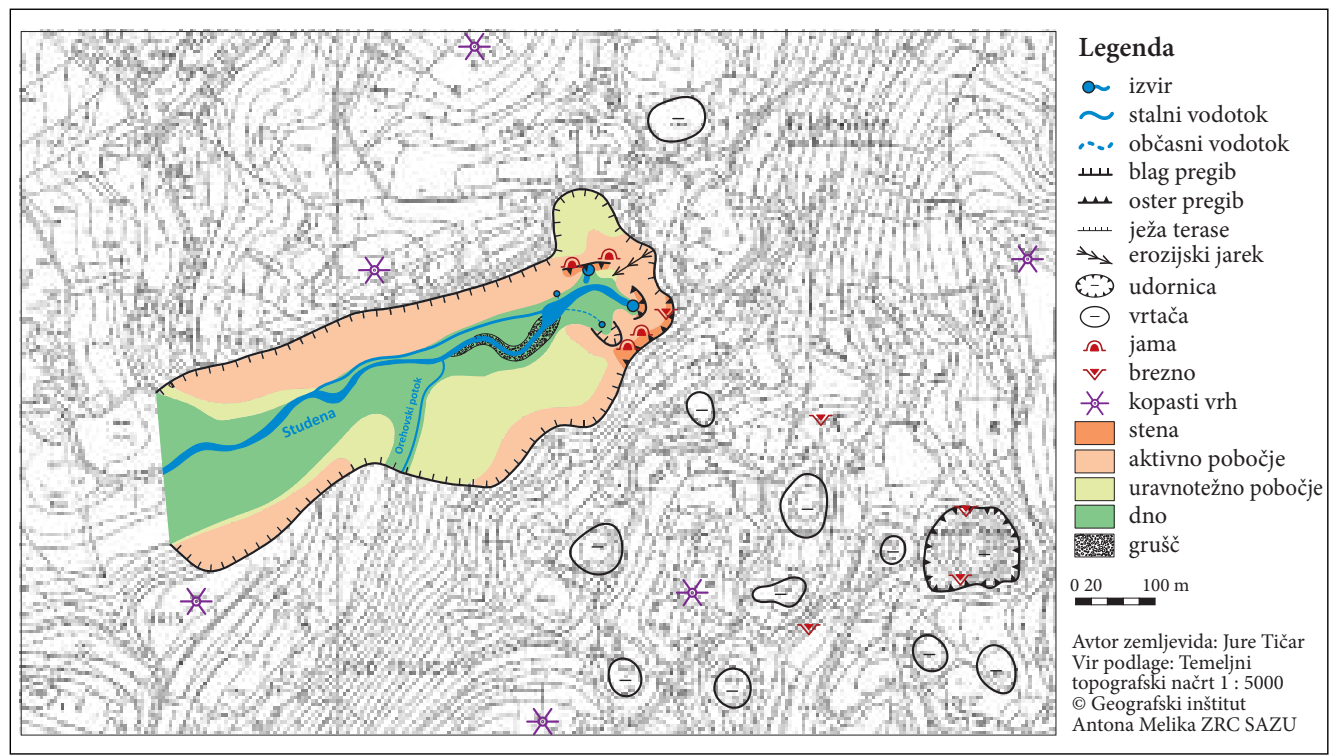

Slika 9: Geomorfološki zemljevid zatrepne doline Studena.

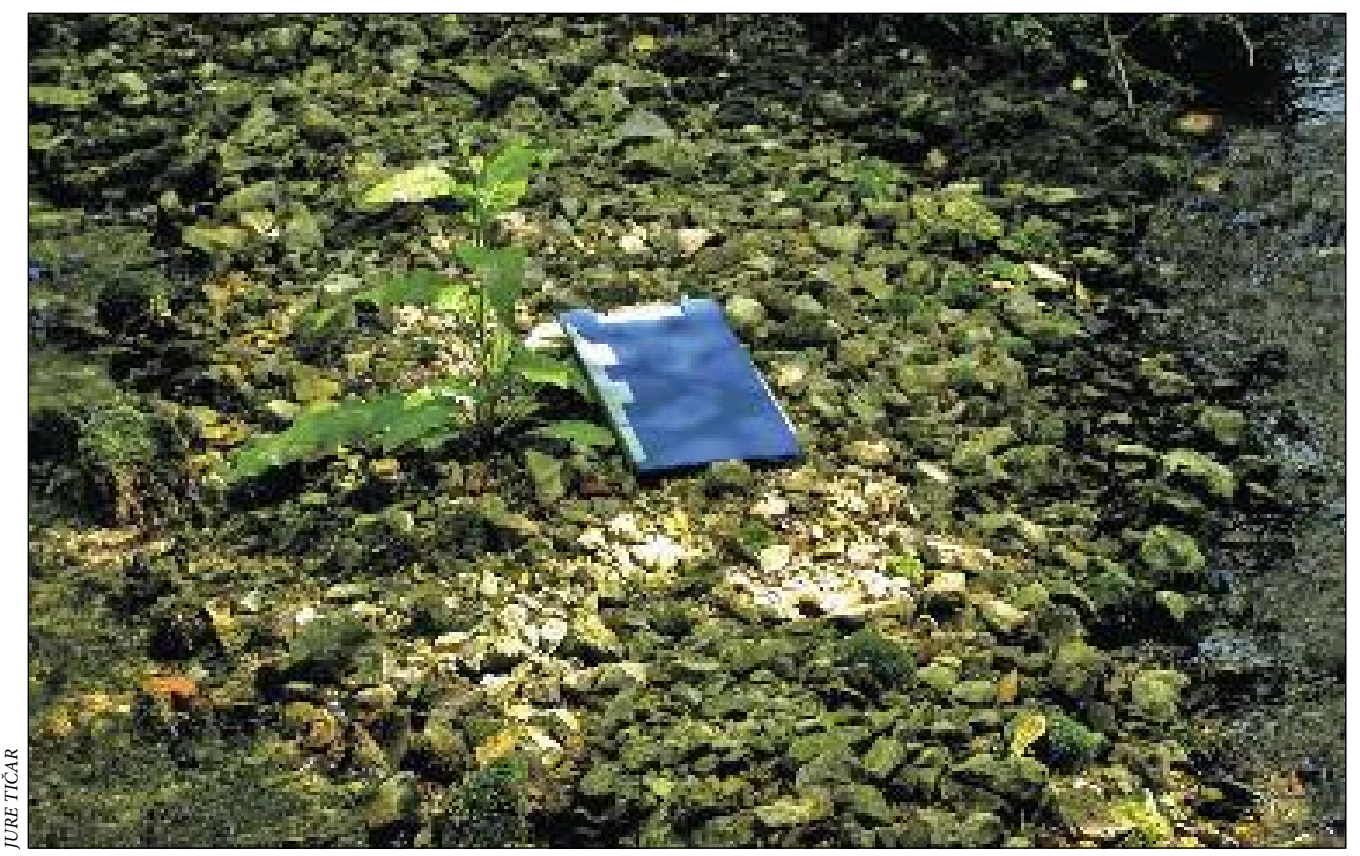

Slika 10: Dno zatrepne doline Studena je prekrito z gruščem. 


\section{Razprava}

Zatrepi so najbolj značilna oblika zatrepnih dolin, saj imajo praviloma stenasta pobočja, ki se strmo dvigajo visoko nad izviri. V njih so procesi rasti zatrepne doline najbolj aktivni, saj so pobočni procesi intenzivni, prav tako pa tudi sposobnost vodotokov za odnašanje gradiva. Oblikovanost in velikost zatrepa pa je posredno povezana tudi s pretočnimi značilnostmi vodotokov, saj praviloma nad manj izdatnimi izviri nastajajo manjši zatrepi oziroma ostenja. Takšne primere lahko najdemo v zatrepnih dolinah Močilnik, Planinskem zatrepu, Luknja in Studena. Če je hidrološka aktivnost v zatrepih že zamrla, v njih prevladajo pobočni procesi, ki sčasoma uravnotežijo pobočja in zakrijejo nekdanja ostenja. Takšne procese lahko prepoznamo v Planinskem zatrepu, kjer izvira Cvinger, v zatrepni dolini Malni ter v zatrepni dolini Globočec. Obenem lahko ugotovimo, da je morfološka oblika zatrepa v zatrepni dolini Malni precej stara, saj v njej ne prevladujejo stenasta pobočja, temveč procesi uravnoteženja pobočij. Pobočni procesi v zatrepnih dolinah so intenzivni predvsem na območju zatrepov, v smeri katere se razvija zatrepna dolina. Iz stenastih pobočij v zatrepu, pod katerimi so pogosto tudi melišča, nato v smeri izteka zatrepne doline le-ta prehajajo $\mathrm{v}$ aktivna pobočja $\mathrm{z}$ blagim pregibom oboda zatrepne doline, dokler se pri izteku zatrepne doline povsem uravnotežijo. Obravnavane zatrepne doline so se po večini razvile v jurskih in krednih apnencih, med katerimi se ponekod pojavlja tudi dolomit (slika 11). Prisotnost manj odpornih kamnin vpliva na nastanek erozijskih jarkov in pobočij z manjšimi nakloni. Z raziskavami starosti in hitrosti rasti zatrepnih dolin bi lahko pridobili tudi podatke o razvoju pobočij na kraških območjih.

Terenske raziskave so pokazale, da je nastanek zatrepnih dolin močno odvisen od prelomnih struktur. Prelomi v večji meri vplivajo na smer razvoja zatrepne doline, obenem pa usmerjajo tudi razvoj

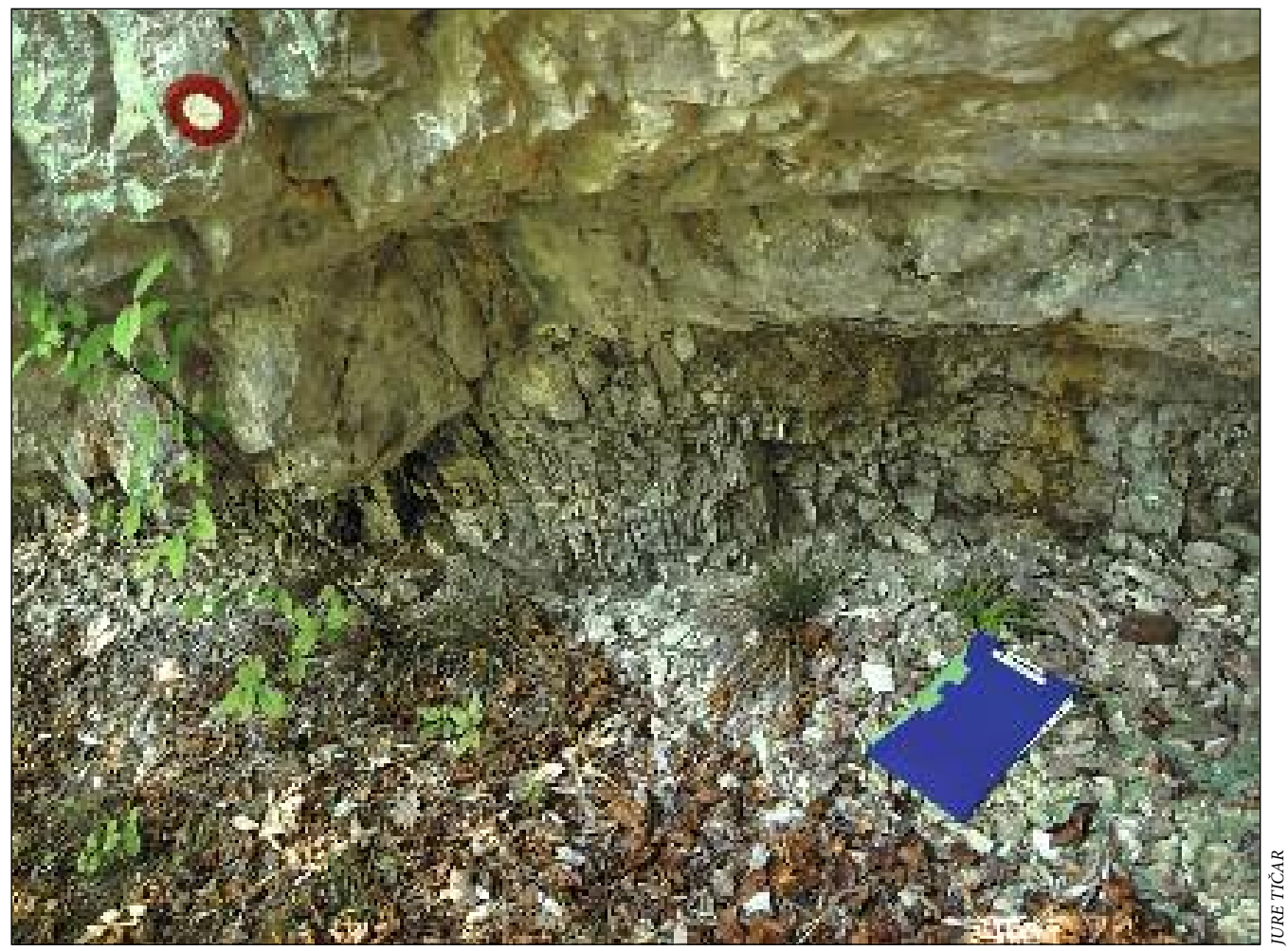

Slika 11: Razlika med preperevanjem dolomita (spodaj) in apnenca (zgoraj) v zatrepni dolini Luknja. 
jam v zaledju ter lego izvirov v zatrepih. $V$ posameznih zatrepih se lahko stika več prelomov, ki rast zatrepnih dolin usmerijo v več smeri. Če ti prelomi potekajo prečno na smer zatrepne doline, lahko ponekod zadenjsko erozijo v tej smeri tudi zaustavijo. Prelomne strukture prav tako vplivajo na nastanek podorov in udornic v zaledju. Zaradi slednjih se spreminjajo tudi hidrološke razmere v zaledju, vključno s prestavljanjem izvirov in posledično oblikovanostjo zatrepne doline. Takšne zatrepne doline, ki imajo več kot en zatrep, smo poimenovali detritične zatrepne doline, saj je njihova rast usmerjena v več kot eno smer. Značilni primeri s slovenskega krasa so zatrepna dolina Retovje, Planinski zatrep, Luknja in Studena.

Prav tako lahko na morfologijo zatrepnih dolin močno vplivajo jamski sistemi. Skupaj s prelomnimi strukturami in pretočnimi značilnostmi usmerjajo razvoj zatrepne doline. Obenem pri freatičnih jamskih zatrepih v zaledju velikokrat nastajajo udornice, ki se združujejo z zatrepnimi dolinami. Pri globokih freatičnih sistemih, je lahko rast zatrepa močno upočasnjena. Razporeditev freatičnih zank torej obenem vpliva tudi na dinamiko rasti zatrepne doline. Jamski sistemi pa lahko na izoblikovanost zatrepov vplivajo tudi s sedimentacijskimi in hidrološkimi spremembami, ki se kažejo v občasni hidrološki neaktivnosti posameznega zatrepa (Planinski zatrep). Rezultati raziskave obenem potrjujejo, da zatrepne doline ne nastajajo $\mathrm{s}$ porušitvijo jamskega stropa, ker $\mathrm{v}$ zatrepnih dolinah prevladujejo predvsem pobočni procesi v kombinaciji z odnašanjem in delnim raztapljanjem gradiva v vodotokih. Med preučenimi zatrepnimi dolinami $v$ zatrepih ni bilo odkritih podorov, ki bi dokazovali podiranje jamskega stropa. Porušitev jamskega stropa se lahko pojavlja zgolj ob reliktnih in hidrološko neaktivnih zatrepnih dolinah, ki so izpostavljene zgolj denudacijskim procesom raztapljanja kraškega površja. V takšnem primeru pa porušitev jamskega stropa vpliva zgolj na preobrazbo zatrepne doline in ne neposredno na njen nastanek.

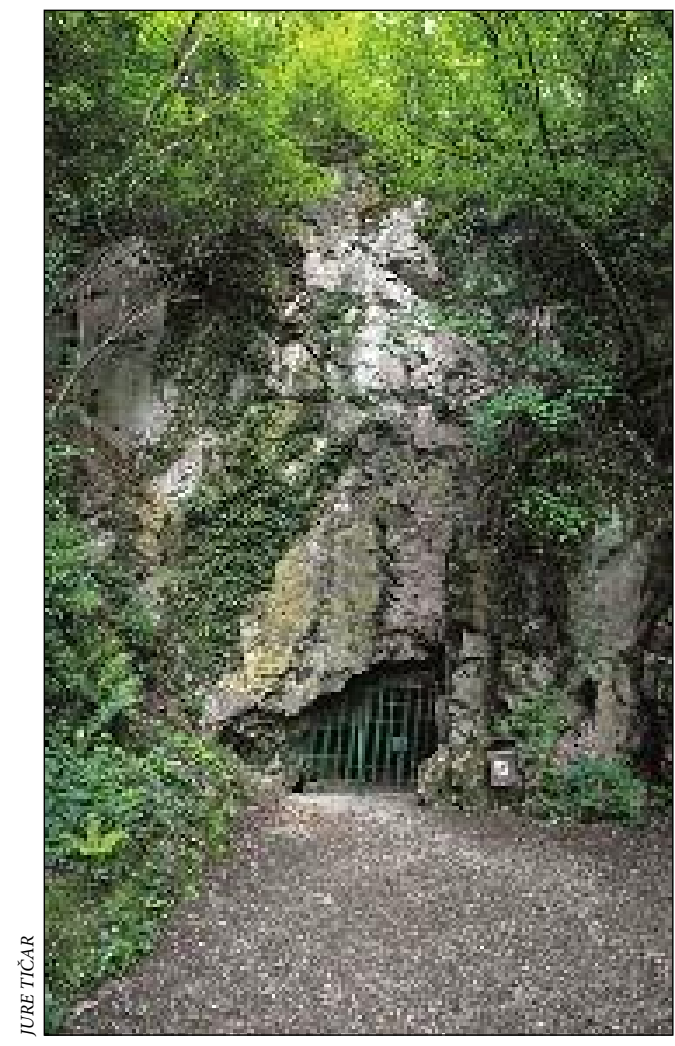

Slika 12: Vhod v Kostanjeviško jamo se odpira $15 \mathrm{~m}$ nad dnom zatrepne doline Studena. 
Nastanek in razvoj zatrepnih dolin je pogosto vezan tudi na združevanje z drugimi reliefnimi oblikami v zaledju. V zatrepni dolini Retovje tako zatrep Malo Okence in udornico Susmanov dol loči manjši ozek $15 \mathrm{~m}$ visok pregib. S postopno rastjo zatrepa Malo Okence bo verjetno prišlo do združitve z udornico in posledično do odstranitve ilovnate zapolnitve $\mathrm{v}$ udornici. Podoben proces je razviden $\mathrm{v}$ izteku zatrepne doline, kjer se je jugovzhodno od izvira Pod orehom izoblikovala z boka odprta udornica Matjaževka, ki je bila pozneje zasuta s sedimenti in antropogeno preoblikovana. Obravnavana primera dokazujeta, da lahko na izoblikovanost zatrepnih dolin vpliva tudi združevanje $\mathrm{z}$ udornicami oziroma vrtačami. Podoben proces je bil raziskan tudi v primeru Planinskega zatrepa, kjer je nad trenutno aktivnim zatrepom, z boka odprta udornica, ki jo zasledimo tudi v začetku Severnega rova. V primeru zatrepne doline Studena smo preučili združevanje zatrepne doline z vrtačo, ki se odpira v severnem delu zatrepa. Posamezne vrtače oziroma udornice pa se lahko oblikujejo tudi v samem zatrepu, v primeru, da se je zatrep v zadnji fazi razvoja poglobil. Takšen je primer v zatrepni dolini Luknja, kjer se je v nekdanjem zatrepu oblikovala udornica z melišči, kar kaže na aktivno grezanje gradiva nad sedanjim podzemnim tokom Prečne (slika 13).

Ker so zatrepne doline obenem reliefne oblike, ki so nastale na stiku dveh različnih pokrajinskih enot, regionalni procesi razvoja površja močno vplivajo na njihov razvoj. Dokazi za takšne procese se ohranjajo v oblikovanosti zatrepnih dolin, zaradi česar so posebej primerne za preučevanje regionalne morfogeneze. Značilen je primer razvoja zatrepnih dolin Planinski zatrep in Malni. V obdobju pred 80.000 leti (Gospodarič 1976) se je začelo vrezovanje zatrepne doline Planinski zatrep na višini $460 \mathrm{~m}$. V tem času so se oblikovale osnovne reliefne oblike zatrepne doline, v Planinski jami pa je že obstajal vzhodni stranski rov na vhodnem delu, v katerem je kasneje nastala udornica (Gospodarič 1976). V tem obdobju je najverjetneje že obstajala tudi zatrepna dolina Malni, ki je prevajala vode iz območja Javornikov in morda tudi Raka (Šušteršič, Šušteršič in Stepišnik 2002). V naslednji fazi razvoja zatrepne doline Planinski zatrep sledi zmanjšanje oziroma prekinitev hidrološke aktivnosti v času pred 80.000 do 30.000 leti, ko je tok Unice iztekal skozi Rakov rokav v Malne (Gospodarič 1976). Dokaz za premik vodnega toka je po mnenju Gospodariča predvsem odkritje grušča v Rakovem rokavu, ki ustreza kamninski sestavi gradiva izpod Planinske koliševke. To gradivo naj bi v Planinski jami oblikovalo podzemni vršaj, ki se od pritočnega dela Pivškega rokava znižuje v Rakov rokav. Takšna razporeditev sedimentov pa ne bi bila mogoča ob aktivnem toku iz smeri Rakovega rokava. Premor v hidrološki aktivnosti Planinskega zatrepa lahko pripisujemo nenadnim reliefnim spremembam v Severnem iztočnem rovu iz Planinske jame, pri čemer lahko sklepamo na podore in zatrpanje $\mathrm{z}$ alogenimi sedimenti. V zatrepni dolini so prevladovali procesi uravnoteženja pobočij, ki so najverjetneje nasuli dno in pobočja zatrepne doline $\mathrm{z}$ gruščem (slika 14). V enakem obdobju so se v območje Malnov stekale vode iz celotnega zalednega območja, zaradi česar lahko sklepamo, da je bila rast zatrepne doline Malni takrat najinten-

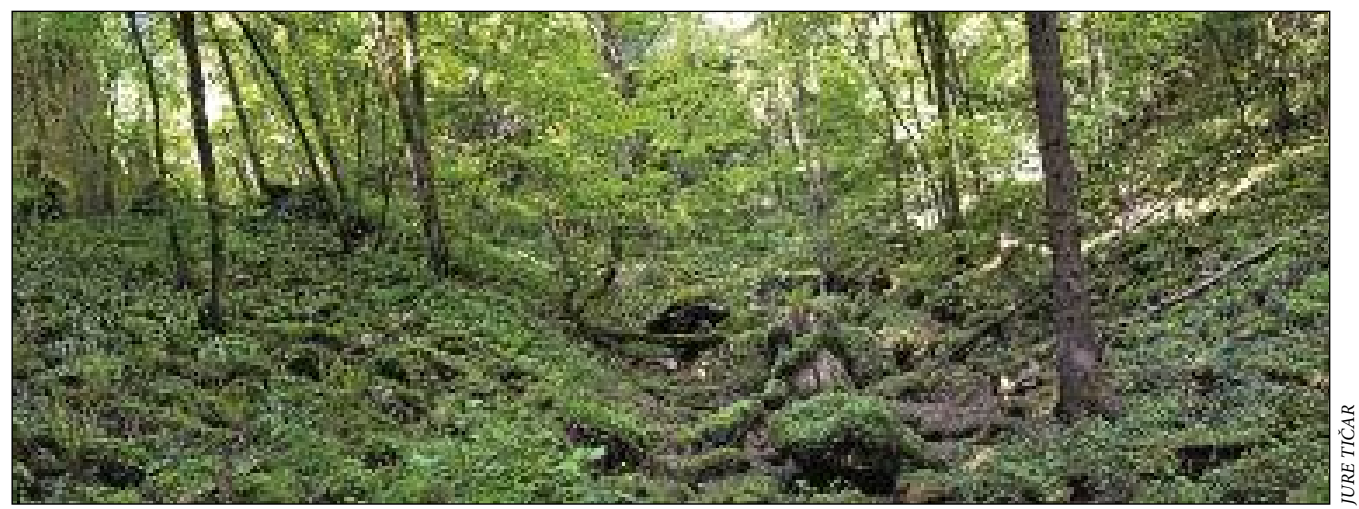

Slika 13: Udornica v zaledju izvira Prečna. 
zivnejša. Gospodarič (1976) pripisuje poseben pomen pri oblikovanju zatrepne doline Malni tudi prodonosnosti reke Unice, ki se je tako lažje vrezovala v matično kamnino. Kasnejša reaktivacija Severnega rova in iztek Unice v sedanji smeri je bila datirana v čas pred 30.000 do 10.000 leti (Gospodarič 1976). Temu dogodku lahko pripišemo tudi oblikovanje melišč v osrednjem delu zatrepne doline, ko se je dno zatrepne doline poglobilo, ob tem pa so začeli delovati intenzivni pobočni procesi. Šušteršič, Šušteršičeva in Stepišnik (2002) izpostavljajo pri prestavitvi toka Unice vdor reke Rak. Ta naj bi domnevno zaradi zasutja severnih ponorov z vršajem Cerkniščice (pred okrog 55.000 leti) na Cerkniškem polju močno povečal pretok v smeri Planinskega polja. S ponovno vzpostavitvijo pretoka Unice skozi zatrepno dolino Planinski zatrep se je začela njena nadaljnja rast, ki je vidna predvsem v oblikovanju ostenja v zatrepu. Ostenje se je razvilo tudi v smeri udornice nad zatrepno dolino, kar kaže na postopno združevanje z omenjeno reliefno obliko. Obenem so se predhodno povečani kanali v zatrepni dolini Malni zapolnili s sedimenti, saj so sedanji pretoki v Malnih močno pridušeni.

Razvoj zatrepnih dolin je močno odvisen tudi od erozijske baze, ki determinira poglabljanje zatrepne doline. Ob tem lahko zasledimo zniževanje izvirov ter oblikovanje sekundarnih zatrepov ali oblikovanje teras v zatrepnih dolinah. Takšne zatrepe, ki so nastali z zniževanjem erozijske baze, smo prepoznali v zatrepni dolini Malni, Globočec, Luknja in Studena. Na primeru zatrepnih dolin Močilnik in Retovje smo prepoznali vpliv fluvioperiglacialnega vršaja Bele (Šifrer 1983) na oblikovanje teras. $\mathrm{V}$ würmu je namreč omenjeni vršaj nasul debelo naplavino pred izviri Ljubljanice in s tem krajevno zvišal erozijsko bazo. V zatrepnih dolinah so tako nastale terase, ki so v zatrepni dolini Močilnik še posebej izrazite, saj je vzhodno od mostu v nadmorski višini okrog $295 \mathrm{~m} 120 \mathrm{~m}$ dolga in $30 \mathrm{~m}$ široka terasa. Če se raven erozijske baze v določenem delu razvoja ne znižuje, lahko to vpliva tudi na uravnavanje dna zatrepne doline. Takšen primer je v izteku zatrepne doline Globočec. V primeru, da se erozijska baza v razvoju močno spreminja, to vpliva tudi na razvoj živoskalnih teras. Takšne terase so še posebej izrazite v zatrepni dolini Luknja. Spodnji deli pobočij v osrednjem delu zatrepne doline pod nadmorsko višino $190 \mathrm{~m}$ so strmi, nad omenjeno ravnjo pa so živoskalne terase, ki v zgornjem delu prehajajo v blaga pobočja. Strma pobočja nad strugo Prečne v povezavi z živoskalnimi terasami dokazujejo, da se je zatrepna dolina v zadnji fazi razvoja poglobila vsaj za 20-25 m. Nekdanje dno zatrepne doline je bilo

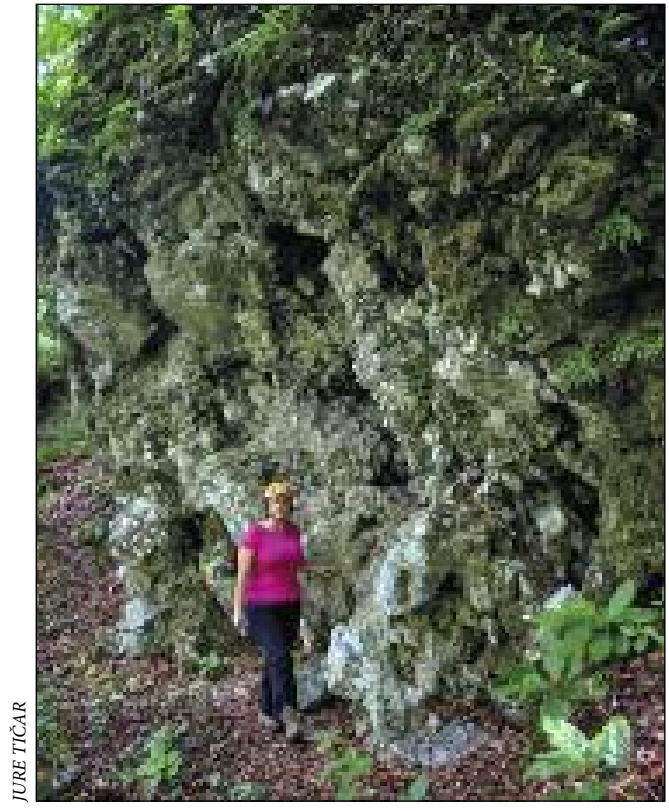

Slika 14: Pobočna breča na vzhodnem pobočju zatrepne doline Planinski zatrep. 
v predhodnih fazah razvoja oblikovano v nadmorski višini med 190 in 195 m, kar je razvidno iz nastanka živoskalnih teras južno od Lukenjske jame. Obenem omenjeno trditev potrjuje tudi prisotnost vhodov v posamezne manjše jame, ki se odpirajo v enaki nadmorski višini, kot so se izoblikovale živoskalne terase. Večje dimenzije rova v Jami za gradom Luknja, ter neposredna bližina izvira Prečne, nakazujejo, da je bila to nekoč izvirna jama. Pri pregledu vrezovanja erozijske baze reke Krke ugotovimo, da se je Krka v 10 km oddaljenem Dolnjem kotu (nadmorska višina okrog 200 m) vrezala 30 m globoko v višje ležeče terase, v zatrepni dolini Luknja pa lahko zasledimo dokaze o vrezovanju Prečne 20-25 m globoko. Zaradi tega lahko sklepamo, da vrezovanje Prečne ni bilo povezano zgolj z lokalno spremembo erozijske baze, temveč $\mathrm{z}$ večjimi spremembami v porečju Krke v regionalnem merilu.

Pri terenskem delu so bile odkrite tudi posledice obdobnega zviševanja erozijske baze, ki so se odražale na primeru poplav na Planinskem polju in posledično zapolnitvijo zatrepne doline Malni z ilovnatimi sedimenti. V obdobju holocenskih poplav na Planinskem polju (pred $5706 \pm 49$ leti) (Stepišnik s sodelavci 2012; Ferk 2014), se je namreč v zatrepni dolini v več zaporednih poplavnih dogodkih odložilo vsaj $30 \mathrm{~m}$ naplavne laminirane ilovice. Naplavna ilovica je zvišala primarno dno, temu pa so se najverjetneje prilagodili tudi pobočni procesi. Predvidevamo, da je naplavna ilovica ohranila oblikovanost korita v zatrepni dolini, pobočja v zgornjem delu zatrepa pa so postajala vse bolj uravnotežena. Deloma to hipotezo potrjuje meritev električne upornosti tal v naplavni ilovici, ki so jo izvedli Stepišnik s sodelavci (2012). Iz prereza meritev električne upornosti tal je namreč razvidno, da se gradivo z manjšo upornostjo (ilovica), skoraj navpično stika $\mathrm{z}$ gradivom $\mathrm{z}$ večjo upornostjo (matična kamnina).

\section{Sklep}

Zaradi pomanjkanja raziskav na tem področju krasoslovja, smo sistematično preučili geomorfološke značilnosti izbranih zatrepnih dolin v Sloveniji. Namen je bil opredeliti procese v zatrepnih dolinah ter vpliv regionalnih geomorfoloških značilnosti na njihov razvoj. Preučili smo tri kraška območja: območje izvirov Ljubljanice z zatrepnima dolinama Retovje in Močilnik, obrobje Planinskega polja z zatrepnima dolinama Malni in Planinski zatrep ter porečje Krke z zatrepnimi dolinami Globočec, Luknja in Studena.

Zatrepne doline nastajajo predvsem zaradi zadenjske erozije, smer zatrepnih dolin pa je po večini prilagojena geološki sestavi. V zatrepnih dolinah prevladujejo pobočni procesi, ki determinirajo obliko in širino doline in so močno povezani s kamninsko zgradbo. Odpornost kamnin za mehansko in kemično erozijo je v kompaktnejših sedimentnih kamninah (apnenec, dolomit) večja; pojavljajo se aktivna in strma pobočja $\mathrm{z}$ melišči in ostenji. $\mathrm{V}$ nekaterih primerih je vidno združevanje $\mathrm{z}$ drugimi kraškimi oblikami, kot so udornice in vrtače, zato je tem oblikam prilagojena tudi oblikovanost zatrepnih dolin. Pomemben dejavnik preoblikovanja je tudi raven površinske oblike, v katero se zatrepna dolina izteka, saj spremembe lahko vplivajo na močnejše poglabljanje zatrepne doline oziroma uravnoteženost podolžnega prereza vodotoka in s tem posledično zmanjšanje gradienta.

Tipizacija zatrepnih dolin izhaja iz temeljne oblikovanosti in dimenzij zatrepnih dolin ter iz načina nastanka. Glede na obliko smo opredelili linearne in detritične zatrepne doline, glede na nastanek pa epifreatične zatrepne doline ter freatične zatrepne doline. Linearne zatrepne doline imajo oblikovano eno dolino, na začetku katere je en zatrep. Značilni primeri so zatrepne doline Močilnik, Malni in Globočec. Detritične zatrepne doline imajo oblikovano eno ali več dolin, na začetku katerih je več zatrepov, v katerih je opaziti prevladujočo rast zatrepne doline. Značilni primeri so zatrepne doline Retovje, Planinski zatrep, Luknja in Studena. Epifreatične zatrepne doline imajo v zaledju izvirov razvite epifreatične jamske sisteme, njihova pobočja pa so praviloma manj razčlenjena. Značilni primeri so zatrepne doline Planinski zatrep, Malni in Studena. Freatične zatrepne doline imajo v zaledju izvirov razvite freatične jamske sisteme in imajo praviloma razčlenjena pobočja, ki so lahko v nekaterih primerih tudi odraz razpada freatičnih zank. Pogosto se te zatrepne doline združujejo z drugimi kraškimi oblikami, kot so vrtače in udornice. Značilni primeri so zatrepne doline Retovje, Močilnik in Globočec. 


\section{Viri in literatura}

Arhiv hidroloških podatkov za vodomerno postajo Mirke v obdobju 1949-1982. Agencija republike Slovenije za okolje in prostor. Ljubljana, 2015a.

Arhiv hidroloških podatkov za vodomerno postajo Mirke I v obdobju 1949-1982. Agencija republike Slovenije za okolje in prostor. Ljubljana, 2015b.

Audra, P., Mocochain, L., Camus, H., Gilli, É., Clauzon, G., Bigot, J.-Y. 2004: The effect of the Messinian Deep Stage on karst development around the Mediterranean Sea. Examples from Southern France. Geodinamica Acta 17-6. Pariz. DOI: http://dx.doi.org/10.3166/ga.17.389-400

Buser, S., Grad, K., Pleničar, M. 1967: Osnovna geološka karta SFRJ 1:100.000, list Postojna. Zvezni geološki zavod. Beograd.

Buser, S. 1968: Osnovna geološka karta SFRJ 1:100.000, list Ribnica. Zvezni geološki zavod. Beograd.

Čar, J., Gospodarič, R. 1983: O geologiji krasa med Postojno, Planino in Cerknico. Acta carsologica 12. Ljubljana.

Ferk, M. 2014: Kvartarne poplave v porečju Ljubljanice. Doktorsko delo, Filozofska fakulteta Univerze v Ljubljani. Ljubljana.

Ford, D., Williams, P. 2007: Karst Hydrogeology and Geomorphology. Chichester. DOI: http://dx.doi.org/ $10.1002 / 9781118684986$

Frachon, J.-C. 2004: Les reculées du Jura lédonien. Colonne.

Frantar, P. (ur.) 2008: Vodna bilanca Slovenije 1971-2000. Ljubljana.

Gams, I. (ur.) 1973: Slovenska kraška terminologija. Ljubljana.

Gams, I. 2004: Kras v Sloveniji v prostoru in času. Ljubljana.

Gospodarič, R. 1976: Razvoj jam med Pivško kotlino in Planinskim poljem v kvartarju. Acta carsologica 7. Ljubljana.

Goudie, A.S. 2004: Encyclopedia of Geomorphology. London. DOI: http://dx.doi.org/10.4324/9780203381137

Gunn, J. 2004: Encyclopedia of Caves and Karst Science. New York. DOI: http://dx.doi.org/10.4324/ 9780203483855

Habič, P., Gospodarič, R., Habe, F., Kranjc, A., Šušteršič, F. 1976: Osnovna speleološka karta Slovenije. Naše jame 18. Ljubljana.

Hugget, R. J. 2007: Fundamentals of Geomorphology. London. DOI: http://dx.doi.org/10.4324/ 9780203947111

Kataster jam Jamarske zveze Slovenije. Jamarska zveza Slovenije. Ljubljana, 2015.

Kladnik, D., Lovrenčak, F., Orožen Adamič, M. (ur.) 2005: Geografski terminološki slovar. Ljubljana.

Kogovšek, J., Petrič, M. 1998: Značilnosti pretakanja voda v kraškem zaledju Temenice. Acta carsologica 27-2. Ljubljana.

Kogovšek, J., Petrič, M. 2006: Tracer test on the Mala gora landfill near Ribnica in south-eastern Slovenia. Acta carsologica 35-2. Ljubljana.

Kovačič, G. 2011: Kraški izvir Malenščica in njegovo zaledje. Hidrološka študija s poudarkom na analizi časovnih vrst. Koper.

Kranjc, A. 2001: Zatrepna dolina. Enciklopedija Slovenije. Ljubljana.

Lipar, M., Ferk., M. 2015: Karst pocket valleys and their implications on Pliocene-Quaternary hydrology and climate: Examples from the Nullarbor Plain, southern Australia. Eeart-Science Reviews 150. Amsterdam. DOI: http://dx.doi.org/10.1016/j.earscirev.2015.07.002

Melik, A. 1928: Pliocensko porečje Ljubljanice. Geografski vestnik 4. Ljubljana.

Mihevc, A. 1991: Morfološke značilnosti ponornega kontaktnega krasa. Izbrani primeri s slovenskega krasa. Magistrsko delo, Filozofska fakulteta Univerze v Ljubljani. Ljubljana.

Mocochain, L., Audra, P., Bigot, J.-Y. 2011: Base level rise and per ascensum model of speleogenesis (PAMS). Interpretation of deep phreatic karst, vauclusian springs and chimney-shafts. Bulletin de la Societe Geologique de France 182-2. Pariz. DOI: http://dx.doi.org/10.2113/gssgfbull.182.2.87 
Novak, D. 1985: Izvir Globočec in njegovo zaledje. Naše jame 27. Ljubljana.

Novak, D. 2001: Kostanjeviška jama in njena okolica. Bilten Jamarskega kluba Železničar 22. Ljubljana. Pavšič, J. (ur.) 2006: Geološki terminološki slovar. Ljubljana.

Pleničar, M., Premru, U., Herak, M. 1975: Osnovna geološka karta SFRJ 1:100.000, list Novo mesto. Zvezni geološki zavod. Beograd.

Salomon, J.-N. 2006: Précis de Karstologie. Bordeaux.

Stepišnik, U., Ferk, M., Gostinčar, P., Černuta, L. 2012: Holocene floods on the Planina Polje, classical Dinaric Karst, Slovenia. Acta carsologica 41-1. Ljubljana.

Šifrer, M. 1983: Nova dognanja o geomorfološkem razvoju Ljubljanskega barja. Geografski zbornik 23. Ljubljana.

Šušteršič, F. 1977: Geomorfološki razvoj zatrepnih dolin na Planinskem polju. Postojna.

Šušteršič, F., Šušteršič, S., Stepišnik, U. 2002: Mladokvartarna dinamika Planinske jame. Naše jame 44. Ljubljana.

Tičar, J. 2012: Geomorfološke značilnosti zatrepnih dolin v Sloveniji in Franciji. Diplomsko delo, Filozofska fakulteta Univerze v Ljubljani. Ljubljana.

\section{Summary: Geomorphological characteristics of selected pocket valleys in Slovenia}

(edited by DEKS d.o. o.)

This article describes the geomorphological characteristics of selected pocket valleys in Slovenia. Based on a broad literature review and fieldwork, the article summarizes detailed morphographic, morphometric, and speleological analyses of pocket valleys. The main objectives are 1) to describe the geological, hydrological, and speleological characteristics of pocket valleys, 2) to define the morphogenesis of pocket valleys, and 3) to define different types of pocket valleys according to their form and genesis.

Pocket valleys are typical landforms in the outflow part of contact karst. They develop near karst springs, where water emerges from carbonate rocks. In a headward erosion process, the springs cut into the karst surface, and eventually valley-like landforms develop. Above the spring at the beginning of the pocket valley, steep walls develop, also known as cirques. Seven examples of pocket valleys in Slovenia were identified and geomorphologicaly examined in detail. Fieldwork in Slovenia included geomorphological analyses of the rims of the Ljubljana Marsh (Ljubljansko barje), the Planina Karst Polje (Planinsko polje), and the Krka River Basin (Porečje Krke).

Previous studies of pocket valleys have mostly considered the definition of pocket valleys, whereas geomorphological studies have been very rare. Some detailed geomorphological studies that were applied only to certain areas were carried out in the Jura Mountains (Frachon 2004) and on the edge of the Planina Karst Polje (Šušteršič 1977). In undergraduate thesis Tičar (2012) describes geomorphologic characteristics of pocket valleys in Slovenia and France. In the literature, the development of pocket valleys is explained by gravitational erosion of slopes, cave roof collapse, and rockfalls, and their orientation has been explained by geological structure, the effect of cave systems in rims of pocket valleys, and erosive cutting of surface watercourses. Their shape has been explained by filling of bottoms with sediments, dynamics of frost weathering, corrosive effects of water, and biocorrosion (Šušteršič 1977; Kranjc 2001; Frachon 2004; Gams 2004; Salomon 2006; Ford and Williams 2007).

Through geomorphological analysis of pocket valleys in Slovenia, one can distinguish various characteristics of their development.

The Ljubljana Marsh: On the southwest rim of the Ljubljana Marsh, two pocket valleys developed around Ljubljanica Springs. The Retovje Pocket Valley is $770 \mathrm{~m}$ long and has very dendritic morphology with three distinct cirques. Many collapse dolines formed near the rim, which also changed the 
underground course of Malo Okence Spring and Veliko Okence Spring in the past. Collapse dolines joining together were very important for the development of this pocket valley. The Močilnik Pocket Valley is $540 \mathrm{~m}$ long and has a linear morphology with one cirque and smaller walls around Mali Močilnik Spring. Development of this pocket valley is concentrated around Veliki Močilnik Spring, where the cirque is composed of high walls and scree. The development of the Močilnik Pocket Valley was also affected by the Würmian fluvioperiglacial fan of the Bela River, which has filled the bottom at the end of the pocket valley (Šifrer 1983).

The Planina Karst Polje: Two pocket valleys developed on the southwest rim of the Planina Karst Polje. The first is the Planina Pocket Valley (Planinski zatrep), which is $920 \mathrm{~m}$ long and has two cirques: one in front of Planina Cave (Planinska jama) and the Cvinger Cirque at the end of the pocket valley. The development of the pocket valley was greatly affected by fluvial inactivity 80,000 to 50,000 years ago, when the waters of the Unica River discharged into the Malni Pocket Valley. The reason for the lack of flow was probably the collapse of the cave ceiling. During that time, scree probably developed on the slopes in the pocket valley. About 30,000 to 10,000 years ago, the flow rebuilt itself and the current cirque developed. The Malni Pocket Valley is a linear pocket valley; it is $1,200 \mathrm{~m}$ long and has only one cirque. Based on the present discharge of Malenščica Spring and the shape of the valley, it can be assumed that the main effect on the pocket valley's development was the outflow of the Unica River 80,000 to 50,000 years ago (Gospodarič 1976). When the Unica River started to flow along its current course, water filled the former channels with material that may have derived from the Unška koliševka Colappsed Doline, which modified the outflow of Malenščica Spring. The former surface of the pocket valley was later covered with laminated loamy material from high Holocene floods in the Planina Karst Polje to a level of $495 \mathrm{~m}$ (Stepišnik et al. 2012; Ferk 2014). These sediments also preserved the form of the previous bottom of the Malni Pocket Valley, which was not influenced by slope processes later on.

The Krka River Basin:Three pocket valleys have developed in the Krka River Basin. The Globočec Pocket Valley developed in the terrace of the Krka River near the village of Zagradec. The valley is $1,130 \mathrm{~m}$ long and has a linear form with one main cirque and two smaller ones. Above the present cirque, an older cirque was identified, which leads to the conclusion that the pocket valley probably adapted to lowering and cutting into the terrace of the Krka River. The bottom of the valley is narrow and supports the theory of increased erosion. The Luknja Pocket Valley developed near the village of Prečna. The valley is $1,140 \mathrm{~m}$ long and has a dendritic shape with two cirques. About 20 to $30 \mathrm{~m}$ above the present bottom of the pocket valley, former cirques with entrances to epiphreatic caves were identified. At this level some former terraces are also preserved, below which the Prečna River has incised the bottom with active slope processes. At a level of about $240 \mathrm{~m}$, a former cirque developed. The incision of the erosional base has also been identified at the end of the Krka Valley, and therefore it can be assumed that the terraces in the Luknja Pocket Valley also correspond to regional geological changes. The Studena Pocket Valley developed near the town of Kostanjevica na Krki. This valley is $870 \mathrm{~m}$ long and has a dendritic form. The form of the Studena Pocket Valley is determined by a local fault. The growth of the pocket valley is concentrated above Studena Spring and the entrance to Kostanjevica Cave (Kostanjeviška jama), where high walls and scree have developed.

Based on the morphology and genesis of pocket valleys studied, a typization was carried out. Based on their morphology, 1) linear and 2) dendritic pocket valleys were defined. Based on their genesis, 1) epiphreatic and 2) phreatic pocket valleys were defined. Linear pocket valleys are represented by one valley with one cirque above the main spring. Furthermore, the growth of linear pocket valleys is concentrated in only one direction. Typical examples are the Močilnik, Malni, and Globočec pocket valleys. Dendritic pocket valleys have one or more valleys, where multiple cirques and springs have developed and the growth of pocket valleys is dispersed in multiple directions. Typical examples are the Retovje, Planina, Luknja, and Studena pocket valleys. In the hinterland of epiphreatic pocket valleys, which have uniform slopes, epiphreatic cave systems developed. Typical examples are the Planina, Malni, and Studena pocket valleys. Phreatic pocket valleys have phreatic cave systems in the hinterland of pocket valleys 
and uneven slopes. Often these types of pocket valleys join with other landforms such as dolines and collapse dolines. Typical examples are the Retovje, Močilnik, Globočec, and Luknja pocket valleys.

This article presents the results of the first geomorphological study of pocket valleys and examines the morphogenesis of multiple pocket valleys in various karst areas of Slovenia. The lack of geomorphological studies in this field of karst studies is one reason for the shortage of a widely accepted definition of pocket valleys. The results based on a study of the literature and fieldwork are a basis for further investigation of this topic. Because the geomorphological characteristics of pocket valleys also reveal some general characteristics of regional karst areas, it is advisable to focus on further detailed geomorphological analyses of pocket valleys in the future. 